\title{
MODELS OF THE REFERENCE DEPARTURE AND ARRIVAL IFR PROCEDURES FOR THE PURPOSE OF RESEARCH IN RPAS INTEGRATION IN CONTROLLED AIRSPACE
}

\author{
Daniel Lichoń, Marek Orkisz \\ Rzeszow University of Technology \\ Department of Aircraft and Aircraft Engines \\ Powstańców Warszawy Av. 8, 35-959 Rzeszow, Poland \\ tel.: +48 17 743-2346, +48 17 865-1444 \\ e-mail:d_lichon@prz.edu.pl,mareko@prz.edu.pl
}

\begin{abstract}
The air operations in controlled airspace performed according to Instrument Flight Rules (IFR) are composed of three main flight phases, i.e. departure, cruise, arrival. Controlled airspace is divided into the terminal area and en-route airspace. The terminal area encloses the departure and arrival phases while the en-route airspace encloses the cruise phase. The IFR procedures are designed for manned aviation to ensure the safety of air operations. Development of the aviation concerns among others the increase in the number of unmanned aviation operations. Currently, on the European level, there is an on-going, long-term program of integration of the unmanned aviation in the uniform (non-segregated) airspace. This work concerns the research in the integration of the Remotely Piloted Aircraft Systems (RPAS) in the IFR procedures of the controlled airports. The objective was to build the reference models of Standard Instrument Departure and Arrival Procedures (SID and STAR). Basing on the procedure design guidelines the models of procedural nominal track, tolerance area, obstacle clearance area, climb or descend gradient, manoeuvres in SID and STAR were done. The guidelines describe the operational minima thus the statistics of existing procedures was done to select the suitable procedure parameters such as a number of navigational points, segments lengths, altitudes, climb or descent gradients. Reference models of SID include straight departure and turning departure procedures. Reference models of STAR include non-precision approach procedures according to used navigational aids, i.e. GNSS, VOR. The reference procedures were numerically implemented which will be used in the further works on RPAS integration problem by simulations of the RPAS ability to execute of the SID and STAR.
\end{abstract}

Keywords: RPAS integration, SID and STAR, unmanned aviation, controlled airspace, controlled airports

\section{Introduction}

The object of interest in this article was the procedures of departure and arrival according to Instrument Flight Rules (IFR) at the controlled airport areas. The procedures of Standard Instrument Departure and Standard Instrument Arrival Route (SID and STAR) are placed in the terminal area (TA) and describe the procedural air route between the airport and en-route airspace. In the controlled air traffic, the procedures provide the safety of flights, accommodation of different aircraft categories, the fulfilment of noise restrictions, utilization of available navigational aids. From the aircraft performance point of view, the procedural route shape is matched to manned aircraft. It is aimed to accommodate a possibly large number of aircraft categories (according to ICAO categorisation) [5] in the given procedures. The development of aviation includes among the others the regular increase in the number of commercial unmanned operations. However, the majority of unmanned operations are performed in segregated airspace, which limits the use of the unmanned aircraft. Currently, at the European level, there is an on-going process, which aims in integration of the unmanned aviation in uniform (non-segregated) airspace [1-3]. The issue concerned in the work is the integration of the Remotely Piloted Aircraft Systems (RPAS) in the SID and STAR procedures. In the integration process, the unmanned aircraft and manned aircraft are treated equivalently. It is supposed that unmanned aircrafts performances differ from manned 
aircraft due to less weight and dimensions. Therefore, the researches in the fulfilment of SID and STAR procedures by RPAS aircraft are well founded. The undertaken step in this work was to build the reference shape of SID and STAR procedures. The reference procedures' shape was based on ICAO guidance for the design and it performs IFR procedures $[4,5]$. The procedure design guidance includes operational minima. However, the parameters of the existing procedure are often higher due to individual features of airports and surrounding areas. Basing on available procedure charts [6-11] the reasonable parameters of reference procedures such as climb or descent gradients, segments lengths, flight altitudes were chosen. The shape of SID and STAR procedures is connected with navigational aids used, which was included in the models. Prepared models of SID include straight departure and turning departure. Prepared models of STAR include the non-precision approach according to GNSS and VOR navigational aids. The prepared models of SID and STAR will be used in the further works focused on simulations of RPAS flights.

\section{Features of the SID and STAR procedures}

The departure and arrival procedures are composed of navigational points, route segments, turns, altitudes and climb or descent gradients. Mentioned elements shape the nominal track (flight trajectory) along to aircraft is supposed to fly. However, the real flight trajectory is different due to flight technical tolerance, the accuracy of the navigational aids, wind influence. Therefore, the nominal track is surrounded by a tolerance area and minimum obstacle clearance (MOC) area. The tolerance area is the acceptable horizontal deviation from the nominal track while the MOC is the minimal vertical distance from ground obstacles, which must be provided (Fig. 1). The shape and dimension of the tolerance area are dependent on navigational aids used.

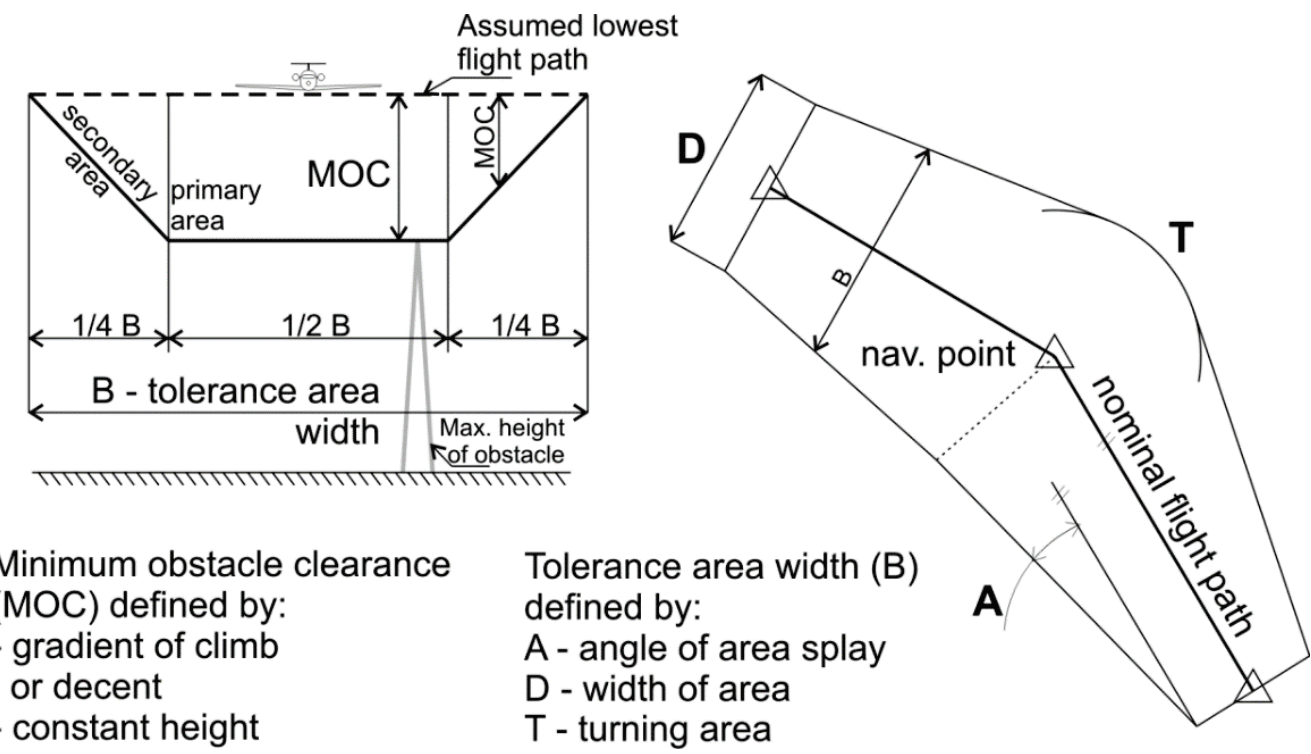

Fig. 1. Profile of the procedural tolerance area (left drawing: the vertical profile, right drawing horizontal profile)

\section{Model of the SID procedures}

The prepared models include straight departure and turning departure. Straight departure is defined if the nominal track bearing after take-off does not exceed $\pm 15^{\circ}$ from the runway bearing. Turning departure is defined if nominal track includes the turn, which exceeds $\pm 15^{\circ}$ from the runway bearing. The models include GNSS and VOR navigational aids. Model of straight departure includes the track adjustment at a specified point. The turning area, which protects the flight technical tolerance and wind influence, was modelled by the bounding circle method [5]. Parameters of the SID procedures were shown in Tab. 1. 
Models of the Reference Departure and Arrival IFR Procedures for the Purpose of Research in RPAS Integration in...

Tab. 1. Parameters of reference SID procedures for straight departure and turning departure

\begin{tabular}{|c|c|c|c|c|c|c|c|}
\hline \multirow{4}{*}{$\begin{array}{c}\text { SID } \\
\text { Straight } \\
\text { (GNSS } \\
\text { navaid) }\end{array}$} & $\begin{array}{c}\text { Area } \\
\text { width } \\
\text { at DER }\end{array}$ & $\begin{array}{l}\text { Area } \\
\text { splay }\end{array}$ & $\begin{array}{l}\text { OIS } \\
\text { gradient }\end{array}$ & $\begin{array}{l}\text { MOC } \\
\text { gradient }\end{array}$ & $\begin{array}{c}\text { PDG } \\
=\mathrm{OIS}+\mathrm{MOC}\end{array}$ & $\begin{array}{c}\text { GNSS } \\
\text { point } \\
\text { tolerance }\end{array}$ & $\begin{array}{c}\text { Track } \\
\text { guidance } \\
\text { distance }\end{array}$ \\
\hline & $150 \mathrm{~m}$ & $15^{0}$ & $2.5 \%$ & $0.8 \%$ & $3.3 \%$ & $0.23 \mathrm{~km}$ & $20 \mathrm{~km}$ \\
\hline & $\begin{array}{c}\text { Primary } \\
\text { area }\end{array}$ & $\begin{array}{c}\text { Secondary } \\
\text { area }\end{array}$ & $\begin{array}{l}\text { Procedure } \\
\text { gradient* }\end{array}$ & $\begin{array}{c}\text { Track } \\
\text { Adjustment }\end{array}$ & $\begin{array}{l}\text { Track adj. } \\
\text { point dist. }\end{array}$ & $\begin{array}{c}\text { Ending } \\
\text { point dist. }\end{array}$ & $\begin{array}{c}\text { Area width } \\
\text { at End }\end{array}$ \\
\hline & Yes & No & $5 \%$ & $15^{0}$ & $\begin{array}{c}1852 \mathrm{~m} \text { from } \\
\text { DER }\end{array}$ & $20 \mathrm{~km}$ & $\begin{array}{l}12.85 \mathrm{~km} \\
\text { calculated }\end{array}$ \\
\hline \multirow{4}{*}{$\begin{array}{c}\text { SID } \\
\text { Turning } \\
\text { (VOR } \\
\text { navaid) }\end{array}$} & $\begin{array}{c}\text { Area } \\
\text { width } \\
\text { at DER }\end{array}$ & $\begin{array}{l}\text { Area } \\
\text { splay }\end{array}$ & $\begin{array}{l}\text { OIS } \\
\text { gradient }\end{array}$ & $\begin{array}{l}\text { MOC } \\
\text { gradient }\end{array}$ & $\begin{array}{c}\text { PDG } \\
=\mathrm{OIS}+\mathrm{MOC}\end{array}$ & $\begin{array}{c}\text { VOR area } \\
\text { splay }\end{array}$ & $\begin{array}{c}\text { Track } \\
\text { guidance } \\
\text { distance }\end{array}$ \\
\hline & $150 \mathrm{~m}$ & $15^{0}$ & $2.5 \%$ & $0.8 \%$ & $3.3 \%$ & $7.8^{0}$ & $10 \mathrm{~km}$ \\
\hline & $\begin{array}{c}\text { Primary } \\
\text { area }\end{array}$ & $\begin{array}{c}\text { Secondary } \\
\text { area }\end{array}$ & $\begin{array}{l}\text { Procedure } \\
\text { gradient* }\end{array}$ & Turn angle & $\begin{array}{c}\text { Turn point } \\
\text { dist. }\end{array}$ & $\begin{array}{c}\text { Ending } \\
\text { point dist. }\end{array}$ & $\begin{array}{c}\text { Area width } \\
\text { at VOR }\end{array}$ \\
\hline & Yes & Yes & $5 \%$ & $45^{0}$ & $\begin{array}{c}2400 \mathrm{~m} \text { from } \\
\text { DER }\end{array}$ & $10 \mathrm{~km}$ & $3.7 \mathrm{~km}$ total \\
\hline
\end{tabular}

(*) - Values based on existing procedures statistics

\section{Model of the STAR procedures}

The prepared models include the non-precision arrival procedures according to GNSS and VOR navigational aids. For selected navigational aids, the different shapes of the nominal track may exist. Therefore, in the models, the following shapes were chosen: straight arrival in GNSS and arrival with racetrack manoeuvre in VOR. The key segments of arrival procedures were modelled, i.e. initial approach, intermediate approach, final approach. These segments form the flight patch, which leads the aircraft from the airspace in the airport proximity to the runway threshold. The models omit the arrival segment, which connects en-route with the terminal area, and missed approach segment, which exists in case of break of the final approach. The modelled segments fulfil the following functions: initial approach lead the aircraft to the point where course of aircraft and runway are adjusted and the altitude is suitable to begin the final descent, intermediate approach is the phase of constant altitude in which the landing configuration of the aircraft is adjusted, final approach is the phase of constant descent to runway threshold. Parameters of the STAR procedures were shown in Tab. 1. The construction of standard VOR arrival procedure segments remains similar to GNSS procedure. Therefore, it was decided to include the racetrack manoeuvre, which is used in order to tighten the procedure area. The racetrack begins above the facility (VOR). The manoeuvre contains reversal turn, outbound track parallel to the final approach track and base turn which leads to the IF or FAF. Dimensioning of outbound track relies on timing (1-3 min) and procedural indicated airspeed based on aircraft category. In the model, the time of $3 \mathrm{~min}$ and indicated airspeed of 205 $\mathrm{km} / \mathrm{h}$ for aircraft A category was chosen. The parameters of the racetrack and procedural segment lengths were shown in Tab. 3. The reference VOR procedure heights and gradients remain as shown in Tab. 2.

Calculation of the protection area of racetrack manoeuvre was done with the use of rectanglesimplified method [5]. The rectangle shaped area with the origin at the facility (VOR) is constructed. The $\mathrm{x}, \mathrm{y}$ coordinate system is placed at the facility where the $\mathrm{x}$-axis is parallel to the outbound track. Positive values of $x, y$-axes are measured on the side, which contains the outbound track. The rectangle dimensions are calculated as follows:

$$
\begin{aligned}
& X_{\max }=T A S *(0.0167 * t+0.0297)+w *(0.0167 * t+0.0381)-1.67+\text { FIXerror }, \\
& X_{\min }=T A S *(-0.0241)+w *(-0.037)+2.04-\text { FIXerror }, \\
& Y_{\max }=T A S *(0.0012 * t+0.0266)+w *(0.0158 * t+0.0368)+0.843 * t-5.37+\text { FIXerror }, \\
& Y_{\min }=T A S *(-0.0015 * t-0.0202)+w *(-0.0167 * t-0.027)+1.3-\text { FIXerror },
\end{aligned}
$$


where:

TAS - aircraft true airspeed,

$\mathrm{t}$ - outbound track time,

$\mathrm{w}$ - omnidirectional wind speed,

FIXerror - error facility position identification (above VOR).

Tab. 2. Parameters of reference approach procedures according to GNSS and VOR navigational aid

\begin{tabular}{|c|c|c|c|c|c|c|}
\hline \multirow{4}{*}{$\begin{array}{c}\text { Initial } \\
\text { Approach }\end{array}$} & Start point & $\begin{array}{l}\text { Descent } \\
\text { gradient }\end{array}$ & $\begin{array}{c}\text { Procedure } \\
\text { height }\end{array}$ & $\begin{array}{l}\text { Segment } \\
\text { length }\end{array}$ & $\begin{array}{c}\text { Area semi } \\
\text { width at IAF }\end{array}$ & MOC \\
\hline & IAF & $4 \%$ & $>\mathrm{MOC}$ & $\mathrm{L}, \mathrm{km}$ & $9.3 \mathrm{~km}$ GNSS & $300 \mathrm{~m}$ \\
\hline & $\begin{array}{c}\text { Descent } \\
\text { gradient* }\end{array}$ & $\begin{array}{c}\text { Procedure } \\
\text { Height* }\end{array}$ & Turn angle* & $\begin{array}{l}\text { Segment } \\
\text { length* }\end{array}$ & $\begin{array}{c}\text { Secondary } \\
\text { area }\end{array}$ & $\begin{array}{c}\text { End } \\
\text { point }\end{array}$ \\
\hline & $2.9 \%$ & $923 \mathrm{~m}$ & $0^{\circ} \mathrm{GNSS}$ & $8.89 \mathrm{~km}$ & Yes & IF \\
\hline \multirow{4}{*}{$\begin{array}{l}\text { Inter- } \\
\text { mediate } \\
\text { Approach }\end{array}$} & Start point & $\begin{array}{l}\text { Descent } \\
\text { gradient }\end{array}$ & $\begin{array}{c}\text { Procedure } \\
\text { height }\end{array}$ & $\begin{array}{c}\text { Segment } \\
\text { length }\end{array}$ & $\begin{array}{l}\text { Area semi } \\
\text { width at IF }\end{array}$ & $\mathrm{MOC}$ \\
\hline & IF & $0 \%$ & Intercept FAF & $\begin{array}{c}9.3<\mathrm{L}<28.0 \\
\mathrm{~km}^{* *}\end{array}$ & \multirow{2}{*}{$\begin{array}{c}\text { GNSS } 5.6 \mathrm{~km} \\
\text { if } \mathrm{L} \geq 6.5 \mathrm{~km} \text { or } \\
5-0.577 \cdot \mathrm{L} \\
\text { if } \mathrm{L}<6.5 \mathrm{~km}\end{array}$} & $150 \mathrm{~m}$ \\
\hline & $\begin{array}{l}\text { Descent } \\
\text { gradient* }\end{array}$ & $\begin{array}{c}\text { Procedure } \\
\text { Height* }\end{array}$ & $\begin{array}{l}\text { Segment } \\
\text { length* }\end{array}$ & $\begin{array}{c}\text { Secondary } \\
\text { area }\end{array}$ & & $\begin{array}{l}\text { End } \\
\text { point }\end{array}$ \\
\hline & $0 \%$ & $665 \mathrm{~m}$ & $8.72 \mathrm{~km}$ & Yes & & FAF \\
\hline \multirow{4}{*}{$\begin{array}{c}\text { Final } \\
\text { Approach }\end{array}$} & Start point & $\begin{array}{l}\text { Descent } \\
\text { gradient }\end{array}$ & $\begin{array}{c}\text { Procedure } \\
\text { height }\end{array}$ & $\begin{array}{l}\text { Segment } \\
\text { length }\end{array}$ & $\begin{array}{c}\text { Area semi } \\
\text { width at } \\
\text { FAF / MAPt }\end{array}$ & $\mathrm{MOC}$ \\
\hline & FAF & $5.2-6.5 \%$ & $\begin{array}{c}\mathrm{H}=\left(\mathrm{FAF}_{\text {Alt }}-\right. \\
\mathrm{MAPt} \mathrm{Alt}-15) \\
\mathrm{m}\end{array}$ & $\begin{array}{c}9.3 \mathrm{~km} \\
\text { (optimum) }\end{array}$ & $\begin{array}{c}3.7 / 1.85 \mathrm{~km} \\
\text { GNSS }\end{array}$ & $75 \mathrm{~m}$ \\
\hline & $\begin{array}{c}\text { Descent } \\
\text { gradient* }\end{array}$ & $\begin{array}{c}\text { Procedure } \\
\text { height* }\end{array}$ & $\begin{array}{c}\text { Segment } \\
\text { length* }\end{array}$ & $\begin{array}{c}\text { Area semi } \\
\text { width at VOR }\end{array}$ & $\begin{array}{c}\text { Secondary } \\
\text { area }\end{array}$ & $\begin{array}{l}\text { End } \\
\text { point }\end{array}$ \\
\hline & $5.2 \%$ & $665 \mathrm{~m}$ & $12.7 \mathrm{~km}$ & $3.7 \mathrm{~km}$ & Yes & $\mathrm{MAPt}$ \\
\hline
\end{tabular}

(*) - Values based on existing procedures statistics

$(* *)$ - For GNSS, VOR the length L may be shorter $L<9.3[\mathrm{~km}]$

Tab. 3. Parameters of reference VOR approach procedure with racetrack manoeuvre

\begin{tabular}{|c|c|c|c|c|c|}
\hline $\begin{array}{c}\text { Aircraft } \\
\text { category }\end{array}$ & $\begin{array}{c}\text { Average } \\
\text { altitude }\end{array}$ & $\begin{array}{c}\text { Aircraft } \\
\text { TAS }\end{array}$ & $\begin{array}{c}\text { Outbound } \\
\text { track time }\end{array}$ & $\begin{array}{c}\text { Outbound } \\
\text { track distance }\end{array}$ & Bank angle \\
\hline $\mathrm{A}$ & $\mathrm{H}=1000 \mathrm{~m}$ & $215.2 \mathrm{~km} / \mathrm{h}$ & $\mathrm{t}=3 \mathrm{~min}$ & $10.76 \mathrm{~km}$ & $25^{\circ}$ \\
\hline $\begin{array}{c}\text { Distance } \\
\text { MAPt-VOR }\end{array}$ & $\begin{array}{c}\text { Distance } \\
\mathrm{MAPt}-\mathrm{FAF}\end{array}$ & $\begin{array}{c}\text { Distance } \\
\mathrm{FAF}-\mathrm{IF}\end{array}$ & $\begin{array}{c}\text { Base turn } \\
\text { radius }\end{array}$ & $\begin{array}{c}\text { Fix error above } \\
\text { VOR }\left(50^{\circ} \text { cone }\right)\end{array}$ & Wind speed \\
\hline $3.85 \mathrm{~km} *$ & $12.7 \mathrm{~km}$ & $1.91 \mathrm{~km}$ & $0.78 \mathrm{~km}$ & $\mathrm{H} \cdot \tan 50^{\circ}=1.19 \mathrm{~km}$ & $\mathrm{w}=99 \mathrm{~km} / \mathrm{h}$ \\
\hline $\mathrm{X}_{\max }$ & $\mathrm{X}_{\min }$ & $\mathrm{Y}_{\max }$ & $\mathrm{Y}_{\min }$ & Secondary area & $\mathrm{MOC}$ \\
\hline $25.4 \mathrm{~km}$ & $-8.0 \mathrm{~km}$ & $13.2 \mathrm{~km}$ & $-12.8 \mathrm{~km}$ & No & $300 \mathrm{~m}$ \\
\hline
\end{tabular}

(*) - VOR facility placed at the runway extension

\section{Visualization of reference procedures}

The models of reference procedures were implemented in the form of points determined by geographical coordinates and altitude. The algorithm, which transforms procedural parameters into a series of geographical points, was built in MATLAB software. This allows using the models in simulations of manned and unmanned flights in SID and STARs. The visualisation of reference procedures was placed in Rzeszow-Jasionka Airport, Poland (EPRZ). Fig. 2-6 shows the reference procedure shapes. The DER and MAPt points represent the runway threshold. 


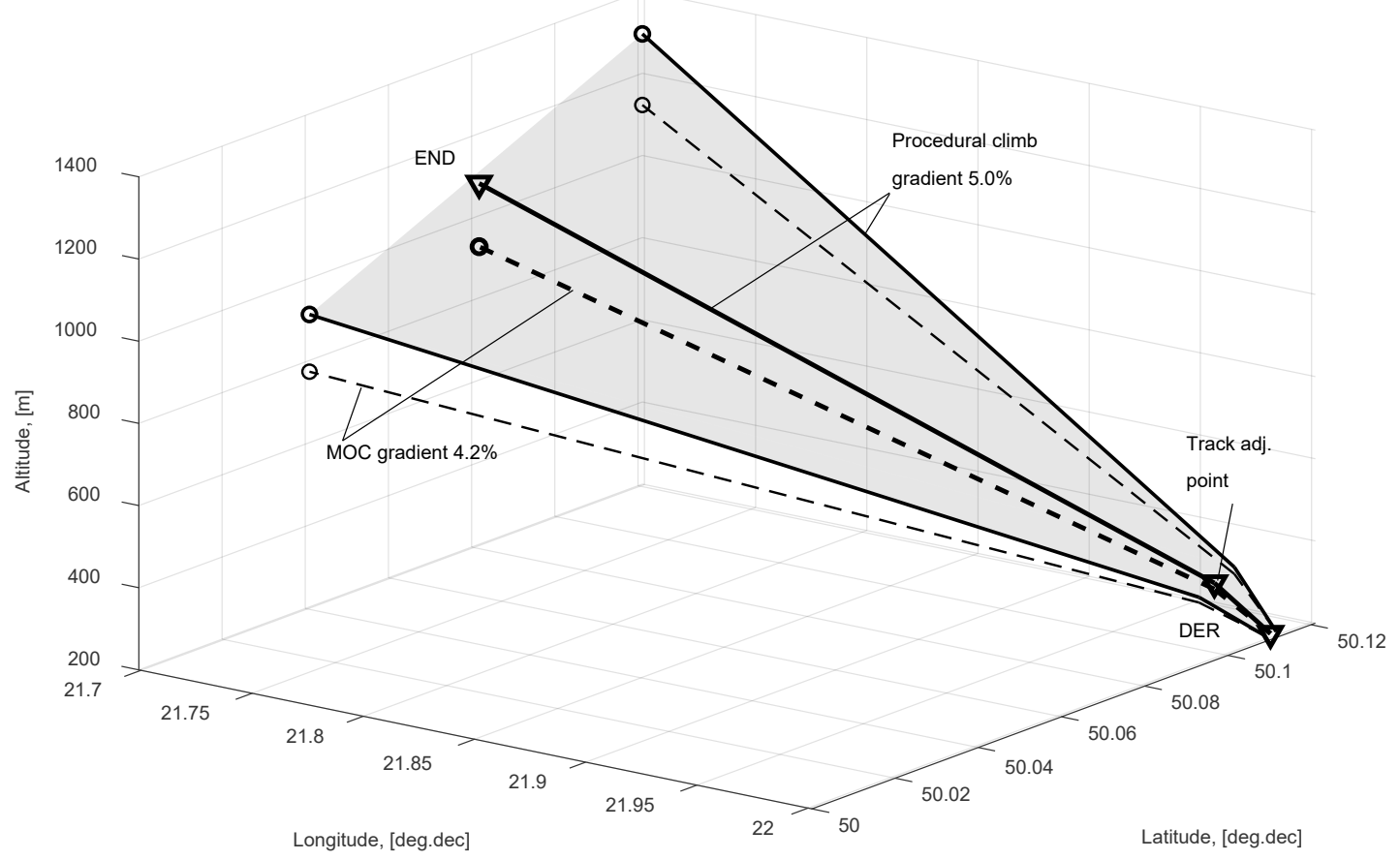

Fig. 2. Reference model of straight departure procedure with track adjustment at the specified point

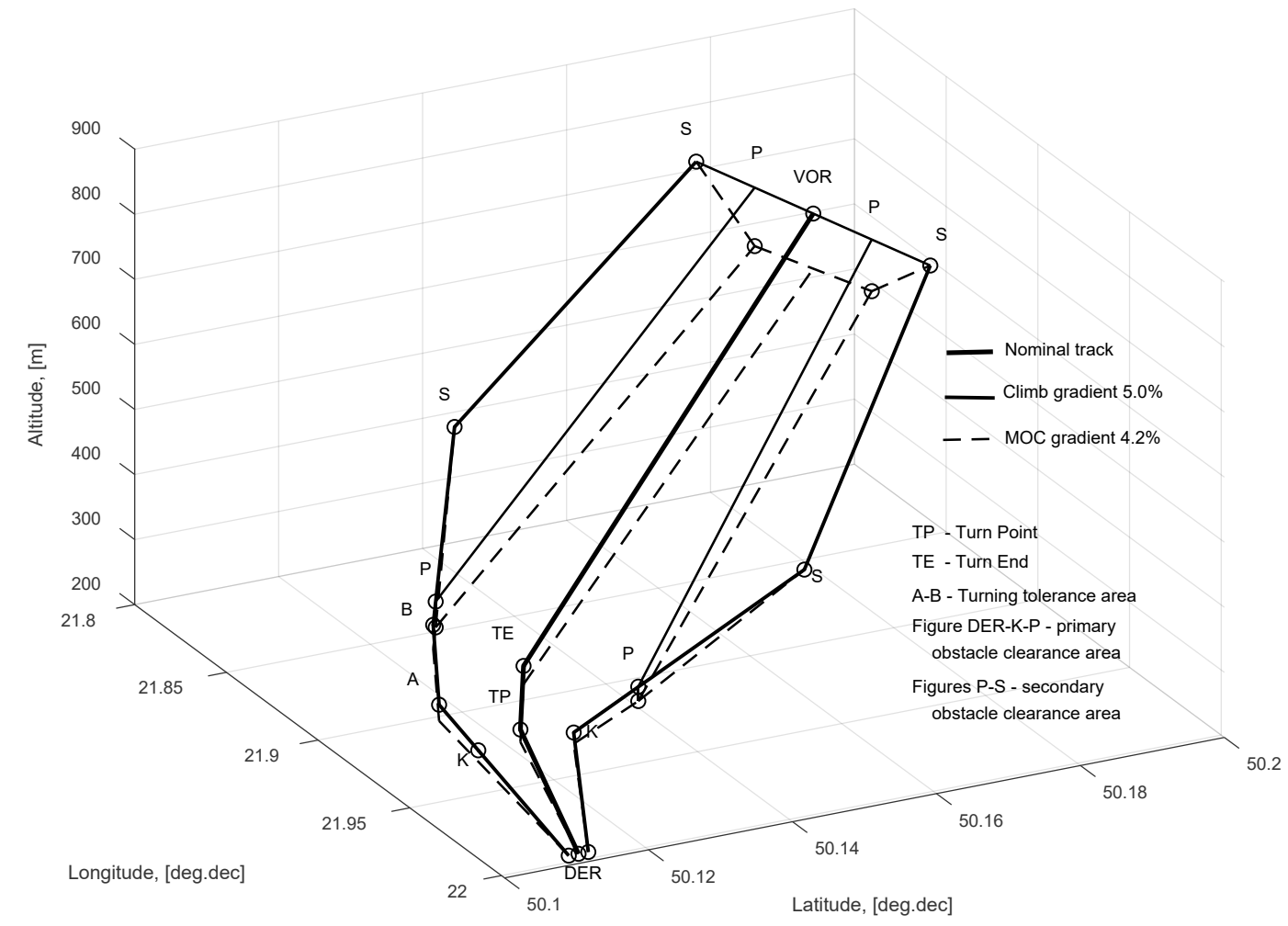

Fig. 3. Reference model of turning departure according to VOR navigational aid (VOR placed ahead)

Visualization of reference VOR racetrack procedure was divided into two parts. The $1^{\text {st }}$ part shows the nominal track, VOR facility and protection area of the final approach segment (Fig. 5). The $2^{\text {nd }}$ part shows the protection area of the racetrack manoeuver (Fig. 6). Note that the racetrack protection area is relatively large and encloses the initial approach and intermediate approach segments. 


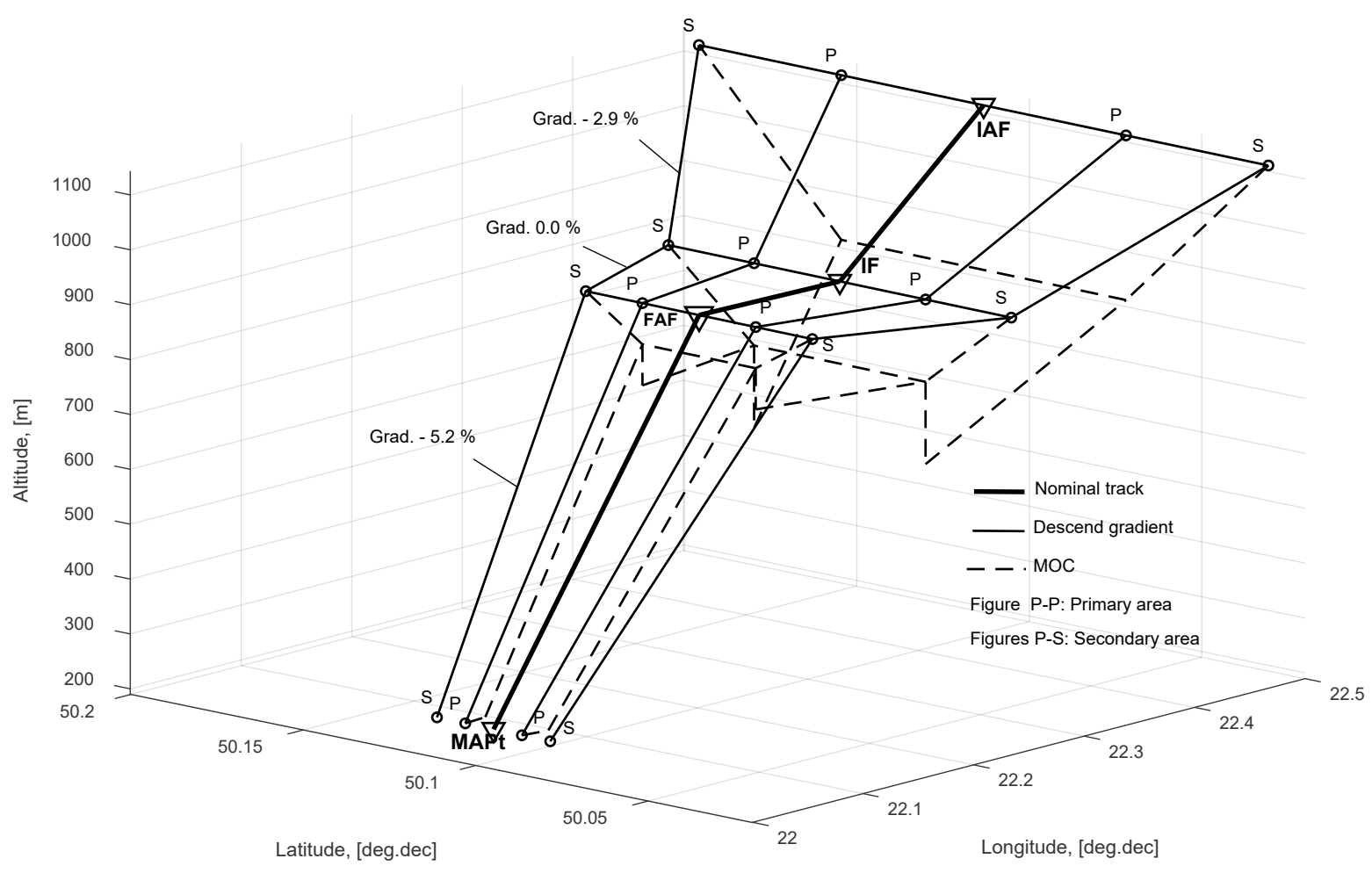

Fig. 4. Reference model of straight arrival procedure according to GNSS navigational aid

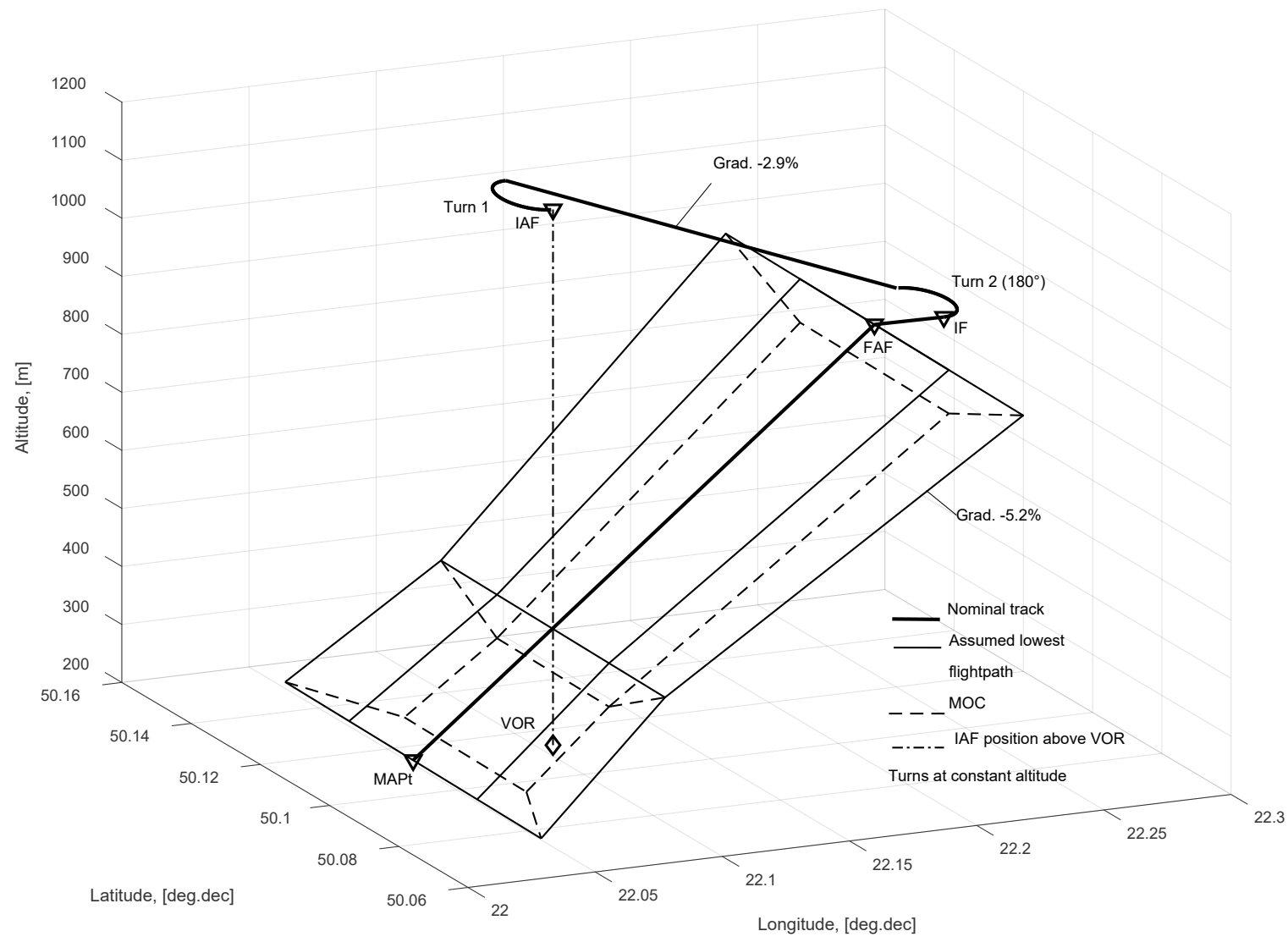

Fig. 5. Reference model of racetrack arrival procedure according to VOR navigational aid 


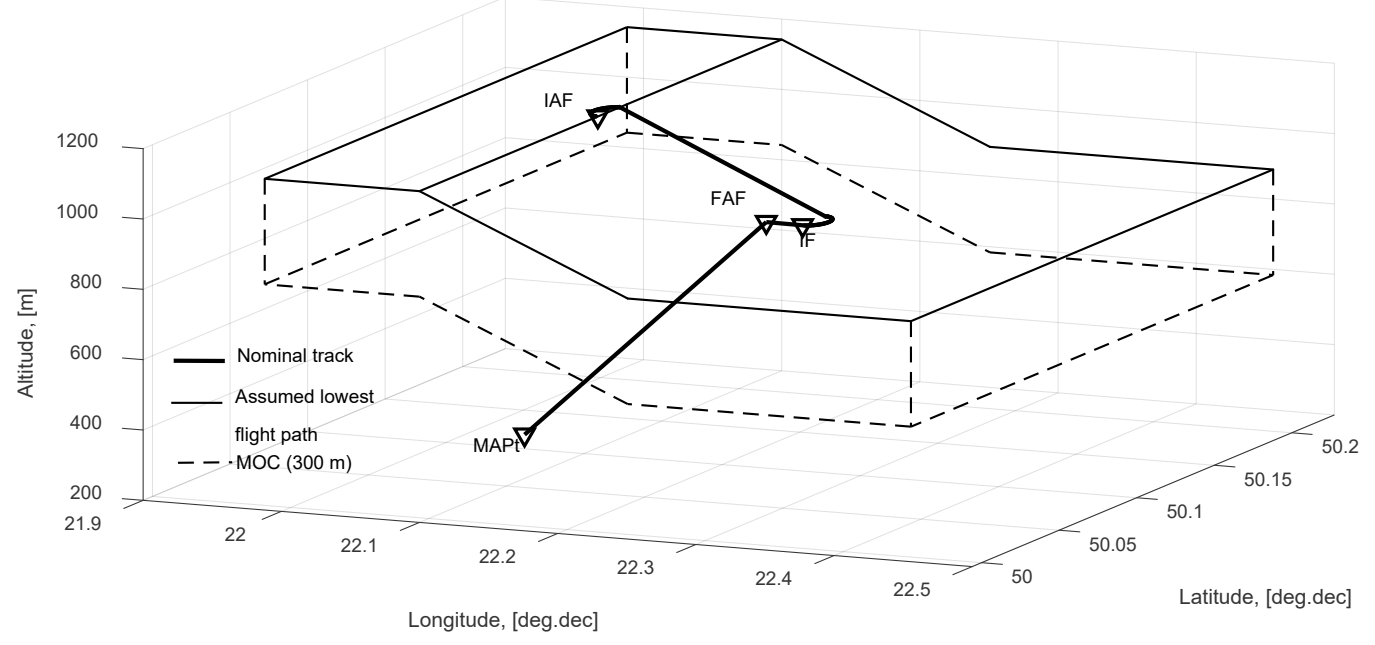

Fig. 6. Protection area of racetrack manoeuvre in reference VOR arrival procedure

\section{Conclusions}

Reference models of SID and STAR procedures own the shape close to analysed existing procedures of controlled aerodromes. The operational requirements of reference procedures were preserved. In the work progress, it was noticed that the climb gradients of SID procedures are higher than required operational minima. The chosen climb gradient was $5 \%\left(2.9^{\circ}\right)$ while the operational minima are PDG $=3.3 \%\left(1.9^{\circ}\right)$. The distance in SID procedures was based on required track guidance distance from DER point, which is equal to $20 \mathrm{~km}$ in straight departure and $10 \mathrm{~km}$ in turning departure. For the reference STAR procedures, the descent gradient of final approach was $5.2 \%\left(3.0^{\circ}\right)$ in both GNSS and VOR procedure. This value predominated in analysed existing procedures. The intermediate approach gradient was specified as $0 \%$; however, it was not common in existing procedures. The initial approach gradient was $2.9 \%\left(1.7^{\circ}\right)$ and the value was specified as the average of analysed existing procedures. The distances of GNSS reference procedure segments was specified as $8.89 \mathrm{~km}, 8.72 \mathrm{~km}, 12.7 \mathrm{~km}$ respectively for initial approach, intermediate approach, final approach. The procedural heights were resultant values of gradients and distances. In case of reference VOR racetrack procedure, it should be noticed that the intermediate segment distance of $1.91 \mathrm{~km}$ is close to operational minima equal to $1.9 \mathrm{~km}$. The position of the VOR facility in this procedure was chosen arbitrarily at the extension of runway in the distance of $3.85 \mathrm{~km}$. This simplified the procedure construction keeping the racetrack manoeuvre requirements. The choice of aircraft A category in racetrack was conditioned on the application of reference models to light aircraft. The advantage of prepared models is the presence of tolerance areas since the published procedural charts show the nominal track. The reference models contain the part of procedures in the proximity of the aerodrome where maintain proper obstacle clearance is crucial. The built of algorithms in MATLAB software which transform the procedural parameters into a series of points determined by geographical coordinates and altitude enable to use the reference models in simulations. It is intended to use the models in the simulations of SID and STARs execution by unmanned aircraft (RPAS). The presented work is a part of research in the integration of the RPAS integration in the uniform (non-segregated) airspace. The supposed further step is the validation of reference models using the available flight simulator of manned aircraft in order to confirm the reference procedures realizability.

\section{List of acronyms}

DER - Departure End of Runway

FAF - Final Approach Fix 
GNSS - Global Navigation Satellite System

IAF - Initial Approach Fix

ICAO - International Civil Aviation Organization

IAS - Indicated Airspeed

IF $\quad-$ Intermediate fix

IFR - Instrument Flight Rules

MAPt - Missed Approach Point

MOC - Minimum Obstacle Clearance

OIS - Obstacle Identification Surface

PDG - Procedure Design Gradient

RPAS - Remotely Piloted Aircraft Systems

SID - Standard Instrument Departure Route

STAR - Standard Instrument Arrival Route

TAS - True Airspeed

VOR - Very High Frequency Omnidirectional Radio Range

\section{References}

[1] European Organization for the Safety of the Air Navigation, UAS ATM Integration Operational Concept, $1^{\text {st }}$ edition, 2018.

[2] European RPAS Steering Group, Roadmap for the integration of civil Remotely-Piloted Aircraft Systems into the European Aviation System, 2013.

[3] ICAO, Manual on Remotely Piloted Aircraft Systems (RPAS), $1^{\text {st }}$ edition, 2015.

[4] ICAO, Procedures for Air Navigation Services - Aircraft Operations (PANS-OPS), Vol. I, Flight Procedures, $5^{\text {th }}$ edition, 2006.

[5] ICAO, Procedures for Air Navigation Services - Aircraft Operations (PANS-OPS), Vol. II, Construction of Visual and Instrument Flight Procedures, $5^{\text {th }}$ edition, 2006.

[6] Latvia AIS, Aeronautical Navigation Publication, Latvia, ais.lgs.lv.

[7] Letové Prevádzkové Služby Slovenskej Republiky, Aeronautical Information Services, Slovakia, aim.lps.sk.

[8] LFV Sweden, Aeronautical Navigation Publication, Sweden, aro.lfv.se.

[9] Oro Navigacja, Aeronautical Navigation Publication, Lithuania, www.ans.lt.

[10] Polska Agencja Żeglugi Powietrznej, Aeronautical Navigation Publication, Poland, ais.pansa.pl.

[11] Řízení letového provozu ČR, Aeronautical Information Services, Czech Republic, ais.ans.cz. Manuscript received 05 June 2019; approved for printing 22 September 2019 